\title{
FAKTOR YANG BERHUBUNGAN DENGAN POLA MENYUSUI BAYI DAN ANAK USIA 6-23 BULAN DI INDONESIA
}

\section{Breastfeeding Pattern of Indonesian Children 6-23 Months of Age and Its Associated Factors}

\author{
Yekti Widodo ${ }^{13}$, Sandjaja23 \\ 1 Pusat Teknologi Intervensi Kesehatan Masyarakat, Balitbangkes, Kemenkes RI, \\ Jl. Percetakan Negara No.29 Jakarta \\ 2Pusat Teknologi Terapan Kesehatan dan Epidemiologi Klinik, Balitbangkes, Kemenkes RI, \\ Jl. Percetakan Negara No.29 Jakarta \\ 3Persatuan Ahli Gizi Indonesia (PERSAGI), Jl. Hang Jebat III/F3 Kebayoran Baru, Jakarta Selatan \\ E-mail: fat_han_an@yahoo.co.id; san_gizi@yahoo.com
}

\begin{abstract}
Exclusive breastfeeding for the first 6 months after birth and continued breastfeeding for up to 2 years is a very beneficial. The objectives of the study were to get better insight on the proportion of breastfeeding and its associated factors among Indonesian children to support breastfeeding awareness program. SEANUTS was a multi-centered nutrition study conducted in Indonesia, Malaysia, Thailand, and Vietnam. A subsample of 2.391 Indonesian children 6-23 months of age was analyzed using ANCOVA and multiple logistic regression. The results showed that 4.5 percent of the children were never breastfed. The study showed that factors significantly associated with never being breastfed were child not lived with his/her mother $(O R=5,0)$, mother's education was junior high school or less $(O R=2,7)$, and child caregiver was not his/her mother $(O R=3,27)$. Delivery helped by private health practitioner or at home was significantly protective against not being breasfed $(O R=0,37)$. The overall proportion of children 6-23 months of age still being breastfed was 73.3 percent. Factors significantly associated with weaning were early weaned $(O R=1,13)$, working mother $(O R=2,0)$, child caregiver not his/her mother $(O R=1,62)$, and not lived with his/her mother $(O R=9,35)$. Factors associated with longer breastfeeding were living in rural areas $(O R=$ 0,69 ), older age of mother $30-39$ years $(O R=0,67)$, delivery at home $(O R=0,45)$ or health practitioner $(O R$ $=0,65$ ). In conclusion, the research indicated that not all babies get breastfeed in an optimal level. Health promotion program to increase breastfeeding awareness should be targeted more for health profesionals in hospital and maternity clinics, mother's education was at junior high school or less, young mother, and in the urban area.
\end{abstract}

Keywords: breastfeeding, weaning, Indonesian children

\section{ABSTRAK}

Menyusui eksklusif selama 6 bulan dan dilanjutkan pemberian ASI sampai anak usia 2 tahun, terbukti sangat bermanfaat. Tujuan penelitian adalah menganalisis faktor yang berhubungan dengan pola menyusui guna mendukung program menyusui di Indonesia. Data merupakan subsampel penelitian SEANUTS Indonesia yaitu anak 6-23 bulan berjumlah 2391. SEANUTS merupakan multi-centered study yang dilakukan di Indonesia, Malaysia, Thailand, dan Vietnam pada tahun 2011. Analisis data dilakukan secara deskriptif dan diuji statistik dengan ANCOVA dan multiple logistic regression. Hasil penelitian menunjukkan proporsi anak yang tidak pernah mendapat ASI adalah 4,5 persen. Hasil analisis menunjukkan faktor yang berhubungan dengan perilaku tidak menyusui yaitu tidak tinggal dengan ibu $(O R=5,0)$, pendidikan ibu SMP ke bawah $(O R=2,7)$, tidak diasuh oleh ibu kandung $(O R=3,27)$. Persalinan di klinik bidan atau di rumah bersifat protektif terhadap perilaku tidak menyusui $(O R=0,37)$. Proporsi anak usia 6-23 bulan yang masih disusui adalah 73,3 persen. Faktor yang berhubungan dengan disapih lebih awal adalah $(O R=1,13)$, ibu bekerja $(O R=2,0)$, pengasuh bukan ibu $(O R=1,62)$, dan anak tidak tinggal dengan ibu $(O R=9,35)$. Faktor yang berhubungan dengan durasi menyusui lebih lama adalah tinggal di perdesaan $(O R=0,69)$, umur ibu $30-39$ tahun $(O R=0,67)$, persalinan di rumah $(O R=0,45)$, di klinik bidan $(O R=0,65)$. Penelitian ini menunjukkan tidak semua bayi mendapat ASI secara optimal. Target program promosi kesehatan untuk meningkatkan pemberian ASI sampai usia 2 tahun adalah petugas kesehatan di rumah sakit, orang tua bayi berpendidikan SMP ke bawah, ibu usia muda, dan di daerah perkotaan.

Kata kunci: pola menyusui, bayi, balita 6-23 bulan 


\section{PENDAHULUAN}

A supan gizi yang memadai pada masa bayi dan masa anak-anak merupakan hal yang esensial untuk menjamin potensi pertumbuhan, kesehatan, dan perkembangan anak. ${ }^{1}$ Kekurangan gizi meningkatkan risiko terhadap penyakit dan berdampak langsung atau tidak langsung terhadap 3,1 juta atau 45 persen kematian anak balita pada tahun $2011 .{ }^{2}$ Kekurangan gizi pada awal kehidupan, dalam jangka panjang dapat merugikan kesehatan dan pertumbuhan serta berdampak terhadap kemampuan intelektual yang lebih rendah ${ }^{3}$ dan menurunkan kemampuan fisik. ${ }^{4}$

Manfaat menyusui telah banyak diteliti dan diketahui baik manfaat untuk bayi maupun ibunya. Manfaat menyusui bagi bayi adalah menurunkan risiko menderita penyakit diare, infeksi saluran nafas akut serta menurunkan risiko kematian akibat penyakit tersebut, juga mengurangi risiko obesitas, diabetes, dan kanker. 5,6 Manfaat menyusui bagi ibu adalah mengurangi risiko perdarahan pasca persalinan serta mengurangi risiko penyakit kanker payudara dan kanker ovarium. ${ }^{7}$ Selain itu menyusui eksklusif juga bermanfaat untuk penundaan kehamilan karena masa tidak haid menjadi lebih panjang.8,9 Secara ekonomi, menyusui bermanfaat bagi keluarga miskin dan masyarakat di negara miskin, dari sisi pengeluaran untuk makanan bayi. ${ }^{10}$ Efek jangka panjang menyusui bayi adalah dapat mencegah obesitas dan meningkatkan kemampuan intelektual. ${ }^{11}$ Hasil studi kohor menunjukkan bahwa dampak jangka panjang menyusui bayi adalah dapat meningkatkan kemampuan intelektual sehingga berpengaruh terhadap peningkatan tingkat pendidikan yang dicapai dan peningkatan pendapatan pada masa dewasa. ${ }^{12}$

Usia dua tahun pertama kehidupan merupakan masa kritis pemberian makan anak untuk menjamin pertumbuhan dan perkembangan anak yang optimal. Fakta menunjukkan bahwa efektivitas intervensi memberikan air susu ibu (ASI) secara optimal dapat mencegah 13 persen kematian anak balita sedangkan memberikan makanan pendamping air susu ibu yang tepat dapat menurunkan 6 persen kematian anak balita. ${ }^{13}$ Pada tahun 2003 WHO dan UNICEF mengembangkan Global Strategy for infant and young child feeding untuk merevitalisasi perhatian dunia terhadap dampak praktik pemberian makan terhadap status gizi, pertumbuhan dan perkembangan, kesehatan serta kelangsungan hidup bayi dan anak-anak. Strategi global rekomendasi WHO tentang pemberian makan yang optimal adalah menyusui eksklusif sampai bayi usia 6 bulan dan memberikan makanan pendamping yang bergizi dan makanan aman sejak bayi usia 6 bulan serta tetap melanjutkan menyusui sampai bayi berusia 2 tahun. ${ }^{14}$

Praktik menyusui telah dilakukan sebagian besar ibu di Indonesia. Data Riset Kesehatan Dasar 2013 menunjukkan bahwa 92,9 persen bayi dan anak umur 0-23 bulan pernah disusui. ${ }^{15} \mathrm{Di}$ Indonesia proporsi bayi yang disusui eksklusif selama 6 bulan masih relatif rendah, namun cenderung meningkat. Hasil Survei Demografi Kesehatan Indonesia 2007, proporsi bayi usia 0-6 yang disusui eksklusif adalah 32 persen dan pada tahun 2012 meningkat menjadi 41 persen. ${ }^{16,17}$ Proporsi bayi yang disusui eksklusif selama 6 bulan masih sangat rendah. Riset Kesehatan Dasar 2010 menyatakan hanya 15,3 persen bayi di Indonesia yang disusui eksklusif selama 5 sampai 6 bulan. ${ }^{18}$ Fakta tersebut menunjukkan bahwa praktik menyusui eksklusif di Indonesia masih rendah. Praktik menyusui dipengaruhi oleh berbagai faktor termasuk faktor sosial ekonomi dan budaya. Artikel ini bertujuan untuk menyajikan informasi tentang faktor yang berhubungan pola menyusui pada bayi dan anak usia 6-23 bulan di Indonesia, berdasarkan data penelitian SEANUTS.

\section{METODE PENELITIAN}

Artikel ini disusun berdasarkan data hasil penelitian SEANUTS (South-east Asian Nutrition Survey) Indonesia yang mencakup 25 provinsi dan 48 kabupaten di seluruh Indonesia pada tahun 2011. Sampel penelitian adalah bayi dan anak usia 6-23 bulan. Data pola menyusui dikumpulkan melalui wawancara untuk menggali informasi tentang riwayat menyusui bayi dan anak usia 6-23 bulan. Wawancara dilakukan menggunakan kuesioner dan dikumpulkan oleh pewawancara yaitu ahli gizi yang sudah dilatih serta dilakukan supervisi pada saat pengumpulan data. Sebelum 
dianalisis data dilakukan proses cleaning data. Kemudian, analisis statistik data pola menyusui dilakukan pembobotan (weighted) berdasarkan jumlah populasi dan sampel di setiap kabupaten. Faktor-faktor yang berhubungan dengan praktik pola menyusui dianalisis dengan analisis uji statistik ANCOVA dan regresi logistik. Penelitian SEANUTS telah mendapatkan ethical clearence dari Komisi Etik Badan Penelitian dan Pengembangan Kesehatan, Kementerian Kesehatan R.I. nomor LB.03.02/KE/6430/2010.

\section{HASIL}

\section{Karakterisitik sampel}

Hasil penelitian tentang karakterisitik 2391 sampel anak usia 6-23 bulan dan rumah tangga disajikan pada Tabel 1. Karakteristik anak tersebut meliputi umur, jenis kelamin, paritas, riwayat tempat persalinan, pengasuhan anak, dan tempat tinggal anak, sedangkan karakterisitk ibu meliputi daerah tempat tinggal, umur ibu, pendidikan ibu, pekerjaan ibu, sosial ekonomi keluarga (kuintil). Faktor-faktor tersebut mempunyai peluang untuk mempengaruhi pola menyusui.

\section{Pola Menyusui di Indonesia}

Informasi tentang pola menyusui bayi dan anak usia 6-23 bulan diperoleh dari wawancara riwayat menyusui. Proporsi bayi dan anak usia 6-23 bulan yang pernah disusui 95,5 persen dan 4,5 persen tidak pernah disusui.

Tabel 1

Karakteristik Sampel dan Orang Tua Sampel Anak 6-23 Bulan di Indonesia (SEANUTS 2011)

\begin{tabular}{|c|c|c|c|}
\hline Karakteristik anak & Persen & Karakteristik rumah tangga/ ibu & Persen \\
\hline Kelompok umur sampel & & Daerah tempat tinggal & \\
\hline $6-11$ bulan & 35,7 & Kota & 49,8 \\
\hline $12-23$ bulan & 64,3 & Desa & 50,2 \\
\hline Jenis kelamin sampel & & Kelompok umur ibu & \\
\hline Laki-laki & 50,3 & $<20$ tahun & 4,9 \\
\hline Perempuan & 49,7 & 20-29 tahun & 54,0 \\
\hline Paritas & & 30-39 tahun & 36,5 \\
\hline Anak 1 & 42,7 & $\geq 40$ tahun & 4,6 \\
\hline Anak 2 & 31,5 & Tingkat pendidikan ibu & \\
\hline Anak $\geq 3$ & 25,8 & $\leq \mathrm{SD}$ & 37,8 \\
\hline Tempat persalinan & & SMP & 24,3 \\
\hline Fasilitas kesehatan & 30,5 & $\geq$ SMA & 37,9 \\
\hline Klinik dokter/bidan & 36,9 & Pekerjaan ibu & \\
\hline Rumah dan lainnya & 32,6 & lbu rumah tangga & 74,9 \\
\hline Pengasuh anak & & Pegawai tetap & 8,4 \\
\hline $\mathrm{lbu}$ & 89,1 & Pegawai tidak tetap & 16,7 \\
\hline Selain ibu & 10,9 & Sosial ekonomi & \\
\hline Tempat tinggal anak & & Kuintil 1 & 20,5 \\
\hline Bersama ibu & 98,9 & Kuintil 2 & 21,4 \\
\hline \multirow[t]{3}{*}{ Tidak bersama ibu } & 1,1 & Kuintil 3 & 19,1 \\
\hline & & Kuintil 4 & 20,4 \\
\hline & & Kuintil 5 & 18,5 \\
\hline
\end{tabular}


Tabel 2

Proporsi Menyusui menurut Karakteristik Sampel dan Orangtua Sampel

\begin{tabular}{|c|c|c|}
\hline $\begin{array}{c}\text { Karakteristik sampel } \\
\text { dan orangtua }\end{array}$ & $\begin{array}{l}\text { \% proporsi menyusui } \\
(\mathrm{X} \pm \mathrm{SE})\end{array}$ & $\mathrm{p}$ \\
\hline Paritas & & 0,003 \\
\hline Anak ke-1 & $69,4 \pm 2,4^{a}$ & \\
\hline Anak ke-2 & $80,4 \pm 2,8^{b}$ & \\
\hline$\geq$ Anak ke-3 & $80,6 \pm 3,2^{b}$ & \\
\hline Tempat persalinan & & 0,006 \\
\hline RS/Rumah bersalin & $68,4 \pm 3,1^{a}$ & \\
\hline Klinik bidan & $83,0 \pm 3,1^{b}$ & \\
\hline Rumah dan lainnya & $75,5 \pm 2,5^{\mathrm{ab}}$ & \\
\hline Pengasuh anak & & 0,002 \\
\hline Ibunya sendiri & $77,7 \pm 1,7^{a}$ & \\
\hline Selain ibu & $61,6 \pm 4,7^{b}$ & \\
\hline Tempat tinggal anak & & 0,004 \\
\hline Bersama ibu & $76,3+1,6^{a}$ & \\
\hline Tidak bersama ibu & $37,1+13,4^{b}$ & \\
\hline Umur ibu & & 0,041 \\
\hline$<20$ tahun & $62,9 \pm 6,4^{a}$ & \\
\hline 20-29 tahun & $74,8 \pm 2,2^{a b}$ & \\
\hline 30-39 tahun & $80,6 \pm 2,8^{b}$ & \\
\hline$\geq 40$ tahun & $67,9 \pm 7,4^{\mathrm{ab}}$ & \\
\hline Pendidikan ibu & & 0,014 \\
\hline$\leq \mathrm{SD}$ & $78,9 \pm 2,7^{b}$ & \\
\hline SMP & $80,4 \pm 3,4^{b}$ & \\
\hline$\geq$ SMA & $69,1 \pm 2,8^{a}$ & \\
\hline Pekerjaan ibu & & 0,000 \\
\hline Ibu rumahtangga & $78,9 \pm 1,8^{a}$ & \\
\hline Pegawai tetap & $55,6 \pm 5,8^{b}$ & \\
\hline Pegawai tidak tetap & $70,1 \pm 4,0 c$ & \\
\hline Status sosial ekonomi & & 0,037 \\
\hline Kuintil-1 & $81,2 \pm 3,7^{b}$ & \\
\hline Kuintil-2 & $78,7 \pm 3,4^{b}$ & \\
\hline Kuintil-3 & $76,8 \pm 3,7^{b}$ & \\
\hline Kuintil-4 & $75,9 \pm 3,7^{b}$ & \\
\hline Kuintil-5 & $65,0 \pm 3,8 \mathrm{a}$ & \\
\hline
\end{tabular}

Tabel 1 menyajikan data proporsi menyusui menurut karakteristik bayi dan anak serta orang tua. Proporsi bayi 6-11 bulan adalah 35,7 persen dan anak usia $12-23$ bulan adalah 64,3 persen dan sebagian besar adalah anak pertama dan kedua. Proporsi sampel berdasarkan jenis kelamin dan daerah tempat tinggal (kota dan desa) tidak berbeda. Sebagian besar sampel diasuh ibu dan tinggal bersama ibu. Jenis pekerjaan ibu sebagian besar adalah ibu rumah tangga dengan usia ibu berkisar antara 20-39 tahun. Proporsi berdasarkan tingkat pendidikan ibu menunjukkan bahwa proporsi tertinggi adalah pendidikan SMA ke atas dan SD. Proporsi menurut tingkat sosial ekonomi menunjukkan bahwa 41,9 persen mempunyai tingkat sosial ekonomi pada kuintil 1 dan kuintil 2. Hasil uji ANCOVA yang disajikan pada Tabel 2 menunjukkan bahwa proporsi menurut karakteristik anak dan orang tua sampel, yang meliputi: paritas, tempat persalinan, pengasuh anak, tempat tinggal anak, umur ibu, tingkat pendidikan ibu, pekerjaan ibu, dan status sosial ekonomi 
keluarga semuanya menunjukkan perbedaan yang signifikan $(p<0.05)$. Hasil analisis menunjukkan bahwa proporsi bayi dan anak usia 6-23 bulan yang masih disusui adalah 74,1 persen dan proporsi yang sudah disapih (tidak disusui lagi) adalah 25,9 persen. Praktik menyusui makin turun dengan makin bertambahnya umur bayi atau anak. Pada umur
6 bulan 88,1 persen bayi masih disusui, namun pada usia 23 bulan anak yang disusui hanya 46,5 persen. Pada bayi dan anak usia 6-23 bulan yang sudah disapih, proporsi bayi dan anak yang disapih sebelum usia 6 bulan sebesar 49,6 persen, 19,7 persen disapih pada umur 6-11 bulan, dan 30,7 persen disapih pada usia $12-23$ bulan.

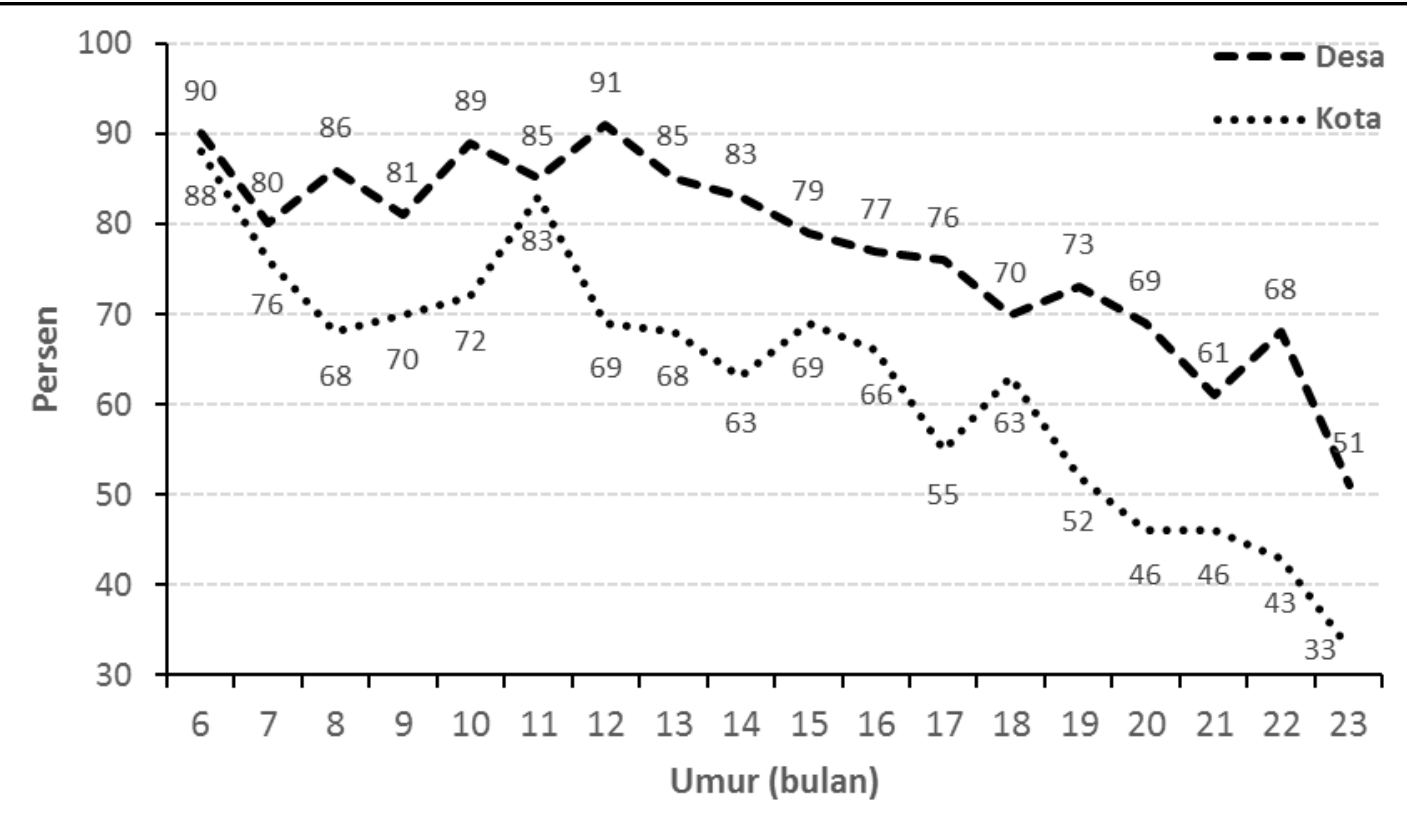

Gambar 1

Tren Proporsi Anak 6-23 Bulan yang Mendapatkan ASI menurut Umur dan Daerah di Indonesia (SEANUTS 2011)

Tabel 3

Hasil Analisis Regresi Logistik Faktor yang Berhubungan dengan Anak 6-23 Bulan yang Tidak Pernah Diberi ASI di Indonesia (SEANUTS 2011)

\begin{tabular}{llll}
\hline \multicolumn{1}{c}{ Variabel } & \multicolumn{1}{c}{ Label } & OR & 95\% Cl \\
\hline Tempat anak tinggal & Bersama ibu & 1,00 & \\
& Tidak bersama ibu & 5,01 & $1,04-25,0$ \\
Pendidikan ibu & SMA atau lebih & 1,00 & \\
& SMP ke bawah & 2,70 & $1,32-5,54$ \\
Tempat bersalin & RS/Rumah bersalin & 1,00 & \\
& Klinik bidan & 0,37 & $0,16-0,82$ \\
Pengasuh utama & lbu kandung & 1,00 & \\
& Bukan ibu kandung & 3,27 & $1,53-7,00$ \\
\hline
\end{tabular}


Tabel 4

Hasil Analisis Regresi Logistik Faktor yang Berhubungan dengan

Penyapihan Bayi dan Anak 6-23 Bulan di Indonesia (SEANUTS 2011)

\begin{tabular}{llcc}
\hline Variabel & \multicolumn{1}{c}{ Label } & OR & $95 \% \mathrm{Cl}$ \\
\hline Umur anak (bulan) & Umur anak & 1,13 & $1,09-1,16$ \\
Daerah & Perkotaan & 1,00 & \\
& Perdesaan & 0,69 & $0,48-0,97$ \\
Tempat persalinan & RS/ RS Bersalin & 1,00 & \\
& Klinik bidan & 0,65 & $0,45-0,94$ \\
& Rumah dan lainnya & 0,45 & $0,29-0,70$ \\
Pengasuh utama anak & lbu kandung & 1,00 & \\
Umur ibu & Selain ibu kandung & 1,62 & $1,01-2,62$ \\
& 20-29 tahun & 1,00 & \\
Pekerjaan ibu & 30- 39 tahun & 0,67 & $0,48-0,93$ \\
& Tidak bekerja & 1,00 & \\
Tempat anak tinggal & Bekerja permanen & 2,02 & $1,19-3,45$ \\
& Bersama ibu kandung & 1,00 & \\
& Tidak bersama ibu & 9,35 & $2,06-42,47$ \\
\hline
\end{tabular}

Proporsi durasi bayi dan anak usia 6-23 bulan mendapatkan ASI atau disusui menurut umur dan daerah tempat tinggal menunjukkan bahwa makin tua usia bayi dan anak makin rendah dan di daerah perkotaan cenderung lebih singkat durasi bayi dan anak mendapatkan ASI.

Gambar 1 menunjukkan bahwa pada bayi usia 6-11 bulan proporsi bayi yang mendapat ASI di daerah perdesaan masih tinggi yaitu berkisar 80-90 persen sedangkan di perkotaan berkisar 68-88 persen. Makin tua usia bayi dan anak makin rendah proporsi bayi yang disusui. Proporsi anak usia 23 yang masih disusui di perdesaan adalah 51 persen sedangkan di perkotaan 33 persen. Bayi dan anak usia 6-23 bulan diharapkan masih disusui sampai usia dua tahun. Faktanya bayi usia 6-23 bulan yang disusui proporsinya makin menurun, sebaliknya bayi yang disapih makin meningkat dengan bertambahnya umur bayi dan anak. Hasil analisis statistik dengan uji regresi logistik menunjukkan bahwa karakteristik ibu dan anak berpengaruh terhadap pola menyusui atau pola penyapihan.

Faktor yang berhubungan dengan pola menyusui atau pola penyapihan bayi dan anak usia 6-23 bulan di Indonesia disajikan pada Tabel 3 dan Tabel 4.

\section{Faktor yang Berhubungan Pola Menyusui di Indonesia}

Pola menyusui yang dimaksud adalah perilaku ibu dalam menyusui bayinya. Faktor yang berhubungan dengan pola menyusui anak usia 6-23 bulan dibedakan menjadi dua yaitu faktor yang berhubungan dengan risiko anak tidak pernah disusui dan risiko anak disapih sebelum usia 2 tahun. Faktor yang berhubungan dengan risiko anak usia 6-23 bulan tidak pernah disusui disajikan pada tabel 3. Hasil analisis menunjukkan bahwa risiko anak tidak pernah disusui berhubungan nyata dengan faktor tempat tinggal bayi atau anak, tingkat pendidikan ibu, tempat bersalin, dan pengasuh utama.

Anak usia 6-23 bulan yang tidak tinggal bersama ibu mempunyai risiko tidak pernah disusui sebesar 5,01 (Cl: 1,04-25,0) kali daripada yang tinggal bersama ibunya. Bayi dan anak dengan ibu yang berpendidikan SMP ke bawah mempunyia risiko tidak pernah disusui sebesar 2,7 (Cl: 1,32-5,54) kali daripada ibu yang berpendidikan SMA ke atas. Bayi dan anak dengan ibu yang tidak diasuh oleh ibunya mempunyai risiko tidak pernah disusui sebesar 3,27 (Cl: 1,53-7,00) kali daripada yang diasuh oleh ibunya. Bayi dan anak yang dilahirkan di klinik bidan atau di rumah mempunyai risiko tidak pernah disusui sebesar 0,37 (Cl: $0,16-$ 
$0,82)$ kali daripada yang dilahirkan di rumah sakit atau rumah bersalin. Artinya anak yang dilahirkan di klinik bidan atau di rumah akan terlindungi dari perilaku tidak pernah disusui dibandungkan dengan anak yang dilahirkan di rumah sakit atau rumah bersalin.

Faktor yang berhubungan dengan perilaku menyapih anak usia 6-23 bulan disajikan pada Tabel 4. Hasil analisis menunjukkan bahwa risiko anak disapih sebelum usia 24 bulan berhubungan dengan umur anak, daerah tempat tinggal, tempat bersalin, pengasuh utama, umur ibu, pekerjaan ibu, tinggal bersama ibu. Risiko anak disapih berhubungan dengan umur anak, artinya makin tua umur anak risiko disapih makin besar. Pertambahan umur anak satu bulan maka risiko anak disapih 1,13 (Cl 1,09-1,16) kali lebih besar daripada umur sebelumnya. Anak yang tinggal di perkotaan mempunyai risiko lebih besar untuk disapih lebih dini daripada anak yang tinggal di perdesaan. Artinya anak yang tinggal di perdesaan lebih terlindungi dari perilaku disapih lebih dini, risiko anak yang tinggal di perdesaan 0,69 (Cl: 0,48-0,97) kali daripada anak yang tinggal di perkotaan.

Anak yang dilahirkan di rumah mempunyai risiko 0,45 (Cl: 0,29-0,70) disapih lebih dini daripada anak yang dilahirkan di klinik bidan dan rumah sakit atau rumah bersalin. Anak yang dillahirkan di klinik bidan mempunyai risiko 0,65 (Cl: 0,45-0,94) disapih sebelum usia 24 bulan, daripada anak yang dilahirkan di rumah sakit atau rumah bersalin. Jadi anak yang dilahirkan di rumah dan di klinik bidan lebih terlindungi dari perilaku disapih lebih dini daripada anak yang dilahirkan di rumah sakit atau rumah bersalin. Risiko anak yang tidak diasuh oleh ibu kandung mempunyai risiko disapih sebelum usia 24 bulan 1,62 (Cl: 1,012,62 ) daripada anak yang diasuh oleh ibu kandung.

Umur ibu juga berhubungan dengan perilaku penyapihan anak usia 6-23 bulan. Anak pada kelompok umur ibu 20-29 tahun mempunyai risiko lebih tinggi disapih sebelum umur 24 bulan. Anak pada kelompok umur ibu 30-39 tahun lebih terlindungi dari perilaku disapih sebelum umur 24 bulan, dengan risiko 0,67 (Cl: 0,48-0,93). Anak dengan ibu yang berkerja secara permanen mempunyai risiko 2,02 (Cl: 1,19-3,45) disapih sebelum usia 24 bulan daripada anak dengan ibu tidak bekerja.
Risiko anak disapih sebelum usia 23 bulan yang tertinggi terjadi pada anak yang tidak tinggal dengan ibu kandung, yaitu sebesar $9,35(\mathrm{Cl}$ : 2,06-42,47).

\section{BAHASAN}

Menyusui bermanfaat untuk meningkatkan kesehatan pada masa bayi, anak, sampai dewasa atau sepanjang hidupnya. Manfaat menyusui bagi bayi dan anak adalah dapat meningkatkan resistensi terhadap penyakit infeksi seperti gastroenteritis, infeksi saluran pernafasan, dan infeksi pada telinga. Bayi dan anak yang disusui mempunyai risiko yang lebih rendah menderita penyakit kronis seperti diabetes, obesitas, asma, dan leukimia. Menyusui juga memberikan keuntungan secara ekonomi yaitu mengurangi pengeluaran untuk biaya pengobatan dan biaya membeli makanan atau minuman formula untuk bayi. ${ }^{19}$ Air susu ibu mengandung berbagai komponen yang dapat memberikan efek protektif terhadap penyakit infeksi serta mempengaruhi sistem imunitas bayi. ${ }^{20}$

Menyusui memberikan manfaat bagi kesehatan bayi dan ibunya, namun tidak semua bayi dan ibu dapat memperoleh manfaat maksimal dari praktik menyusui, karena masih ada bayi yang tidak pernah disusui. Hasil penelitian ini menunjukkan bahwa bayi yang tidak pernah disusui berhubungan nyata dengan keberadaan ibu di mana bayi tidak tinggal dengan ibu kandung dan bayi tidak diasuh oleh ibu kandung. Selain itu juga berhubungan nyata dengan tingkat pendidikan ibu yang rendah (SMP ke bawah) dan tempat persalinan di rumah sakit atau rumah bersalin, dan pengasuh utama bukan ibu kandung. Penelitian di Ghana juga menunjukkan bahwa praktik menyusui lebih banyak dilakukan oleh ibu dengan tingkat pendidikan rendah daripada yang berpendidikan lebih tinggi. ${ }^{21}$

Tabel 3 dan 4 menunjukkan bahwa faktor yang berhubungan dengan pola menyusui pada bayi dan anak usia 6-23 bulan serta risiko tidak disusui dan disusui lebih singkat atau disapih lebih dini. Bayi yang tidak tinggal bersama ibu, tidak diasuh oleh ibu, ibunya bekerja secara permanen, dilahirkan di rumah sakit atau rumah bersalin, tinggal di perkotaan, dan kelompok umur ibu 20-29 tahun mempunyai risiko lebih besar disusui lebih singkat atau disapih lebih 
dini. Pada penelitian ini tingkat pendidikan ibu berhubungan nyata dengan risiko anak tidak pernah disusui, tetapi tidak berhubungan dengan risiko anak disapih lebih dini. Hal tersebut berbeda dengan penelitian Leung et al. $(2006)^{22}$ dan Infant Feeding Surveillance System (2012) yang menunjukkan bahwa durasi menyusui berhubungan nyata dengan tingkat pendidikan ibu, dimana makin tinggi pendidikan makin lama durasi menyusuinya. ${ }^{23}$

Proporsi masih disusui pada anak usia 6-23 bulan yang dilahirkan sebagai anak pertama lebih rendah daripada anak kedua dan berikutnya. Hal tersebut sejalan dengan hasil penelitian Narayan (2005) yang menyatakan bahwa skor menyusui pada anak yang dilahirkan pertama lebih rendah daripada anak yang dilahirkan berikutnya. ${ }^{24}$ Proporsi anak pertama dan kedua lebih tinggi disusui daripada anak ketiga dan berikutnya. Hasil penelitian ini menunjukkan bahwa bayi dan anak usia 6-23 bulan yang dilahirkan di rumah mempunyai risiko disusui lebih lama daripada yang dilahirkan di fasilitas kesehatan, dan yang dilahirkan di klinik bidan juga mempunyai risiko disusui lebih lama daripada yang dilahirkan di rumah sakit. Hal tersebut sejalan dengan penelitian Kalam (2014) yang menyatakan bahwa bayi yang dilahirkan di rumah mempunyai risiko disusui lebih lama daripada yang dilahirkan di fasilitas kesehatan. ${ }^{25}$

\section{SIMPULAN DAN SARAN}

\section{Simpulan}

Proporsi bayi dan anak usia 6-23 bulan yang pernah disusui mencapai 95,5 persen, sehingga masih ada 4,5 persen bayi tidak pernah disusui. Faktor yang berhubungan dengan praktik tidak menyusui bayi dan anak usia 6-23 bulan adalah bayi atau anak tidak tinggal dengan ibu kandung, tingkat pendidikan SMP ke bawah, persalinan di fasilitas kesehatan, dan anak tidak diasuh oleh ibu kandung. Proporsi bayi dan anak usia 6-23 bulan yang masih disusui mencapai 74,1 persen dan proporsinya makin turun dengan makin bertambahnya umur bayi atau anak, sehingga proporsi bayi dan anak yang disapih sebelum usia 2 tahun makin tinggi. Faktor yang berhubungan dengan praktik penyapihan adalah umur anak makin tua, kelompok umur ibu 20-29 tahun, tempat tinggal di perdesaan, bayi atau anak tidak tinggal bersama ibu kandung, ibu mempunyai pekerjaan di luar rumah yang bersifat permanen, melahirkan di rumah sakit atau rumah bersalin, dan bayi atau anak tidak diasuh oleh ibu kandung.

\section{Saran}

Promosi kesehatan yang terkait dengan upaya meningkatkan praktik menyusui bukan hanya ditujukan kepada ibu hamil atau perempuan tetapi juga harus diarahkan kepada petugas kesehatan yang memberikan pelayanan kehamilan dan persalinan di fasilitas kesehatan, kepada pengasuh, dan ibu muda atau yang baru hamil dan melahirkan anak pertama.

\section{UCAPAN TERIMA KASIH}

Penulis dan Tim Peneliti SEANUTS mengucapkan terima kasih kepada Friesland Campina the Nederlands, sebagai pemprakarsa SEANUTS, PT Frisian Flag Indonesia sebagai counterpart di Indonesia. Ucapan terima kasih juga disampaikan kepada Dewan Pimpinan Pusat (DPP) Persatuan Ahli Gizi Indonesia (PERSAGI) yang telah memberikan kesempatan kepada Tim peneliti SEANUTS untuk melaksanakan studi ini.

\section{RUJUKAN}

1. World Health Organization. 2009. Infant and young child feeding : model chapter for textbooks for medical students and allied health professionals. World Health Organization. Geneva.

2. Black RE, Victora CG, Walker SP, Bhutta $Z A$, Christian $P$, de Onis $M$, Ezzati M,Grantham-McGregor S, Katz J, Martorell R, Uauy R. The Maternal and Child Nutrition Study Group. 2013. Maternal and child undernutrition and overweight in lowincome and middle-income countries. The Lancet. 382: 427-51.

3. Pollitt E, Gorman KS, Patrice L. Engle PL, Rivera JA, dan Martorell R. 1995. Nutrition in Early Life and the Fulfillment of Intellectual Potential. Supplement: The INCAP Follow-up Study. J Nutrition. 125: 1111S-1118S. 
4. De Haas J, Murdoch S, Rivera JA, dan Martorell R. 1996. Early Nutrition and Later Physical Work Capacity. Nutrition Reviews. 54(2): S41-48.

5. Much D, Beyerlein $A$, Roßbauer $M$, Hummel S, dan Ziegler AG. 2014. Beneficial effects of breastfeeding in women with gestational diabetes mellitus. Molecular Metabolism. 3: 284-292.

6. Jäger $S$, Jacobs $S$, Kröger J, Fritsche $A$, Schienkiewitz A, Rubin D, Boeing $H$, dan Schulze M B. 2014. Breast-feeding and maternal risk of type 2 diabetes: a prospective study and meta-analysis. Diabetologia. 57:1355-1365.

7. Stuebe A. 2009. The Risks of Not Breastfeeding for Mothers and Infants. Rev Obstet Gynecol. 2(4):222-231.

8. Afifi M. Lactational anemorrhoea and modern contraceptive use among nursing women in Egypt 2003. Oman Med. J 23 (2): 1-6, April 2008.

9. Labbok MH. Transdisciplinary breastfeeding support: Creating program and policy synergy across the reproductive continuum. International Breastfeeding. J 3: 16: 1-8, 2008.

10. León-Cava N, Lutter C, Ross J, dan Martin L. 2002. Quantifying the Benefits of Breastfeeding:A Summary of the Evidence. Pan American Health Organization (PAHO). LINKAGES Project. United States Agency for International Development (USAID).

11. Horta BL dan Victora CG. 2013. Long-term effects of breastfeeding: A Systematic Review. World Health Organization. Geneva.

12. Victora CG, Horta BL, Loret de Mola C, Quevedo L, Pinheiro RT, Denise P, Gigante DP, Gonçalves H, dan Barros FC. 2015. Association between breastfeeding and intelligence, educational attainment, and income at 30 years of age: a prospective birth cohort study from Brazil. Lancet Glob Health. 3: e199-205.

13. Jones G, Steketee RW, Black RE, Bhutta ZA, Morris SS, and the Bellagio Child Survival Study Group. 2003. How many child deaths can we prevent this year?. The Lancet 362: 65-71.

14. World Health Organization. 2003. Global strategy for infant and young child feeding. World Health Organization. Geneva.

15. Kemenkes, Badan Litbang Kesehatan. 2013. Laporan Riset Kesehatan Dasar 2013. Badan Litbang Kesehatan. Kemenkes. Jakarta.

16. Badan Pusat Statistik (BPS), Badan Koordinasi Keluarga Berencana Nasional (BKKBN), Kementrian kesehatan, Macro International. 2008. Survei Demografi Kesehatan Indonesia 2007. Jakarta.

17. BPS, PS, BKKBN, Kemenkes, ICF International. 2013. Survei Demografi Kesehatan Indonesia 2012. Jakarta.

18. Kemenkes, Badan Litbang Kesehatan. 2010. Laporan Riset Kesehatan Dasar 2010. Badan Litbang Kesehatan. Kemenkes. Jakarta.

19. Clark SGJ dan Bungum TJ. 2003. The Benefits of Breastfeeding: An Introduction for Health Educators Californian. $J$ Health Promotion. 1(3): 158-163.

20. Jackson KM dan Nazar AM. 2006. Breastfeeding, the Immune Response, and Long-term Health. Review Artikel. JAOA. 106. 4.

21. Sika-Bright S. 2010. Socio-cultural factors influencing infant feeding practicies of mothers attending welfare clinic in Cape Coast. Department of Sociology and Anthropology University of Cape Coast, Ghana.

22. Leung EYL, Au KYA, Cheng SSW, Kok SY, Lui HK, dan Wong WCW. 2006. Practice of breastfeeding and factors that affect breastfeeding in Hong Kong. Hong Kong Med. J 12:432-6.

23. Infant Feeding Surveillance System. 2012. Focuses Report on Socioeconomic Factors Related to Infant feeding Practices in Durham Region. Durham Region Health Departement.

24. Narayan S, Natarajan N, dan Bawa KS. 2005. Maternal and Neonatal Factors Adversely Affecting Breastfeeding in the Perinatal Period. MJAFI. 61: 216-219. 
25. Kalam IMS. 2014. The Effect of socio demographic factors on exclusive breastfeeding and duration of breastfeeding in
Timor Leste. J Information Technol. 3: 2532. 